DOI: $10.14746 /$ por.2018.1.5

\title{
NEOPOGANIZM JAKO ZAGADNIENIE POSTKOLONIALNE. KONTEKST POLSKI
}

\author{
ToMASZ NAKONECZNY ${ }^{1}$ \\ (Uniwersytet im. Adama Mickiewicza w Poznaniu)
}

Słowa kluczowe: neopoganizm, studia postkolonialne, tożsamość, chrześcijaństwo, Polska Keywords: neopaganism, postcolonial studies, identity, Christianity, Poland

\begin{abstract}
Abstrakt: Tomasz Nakoneczny, NEOPOGANIZM JAKO ZAGADNIENIE POSTKOLONIALNE. KONTEKST POLSKI. „PORÓWNANIA” 1 (22), 2018. T. XXII, S. 91-106. ISSN 1733-165X. Neopoganizm postrzegany jest zwykle jako zjawisko marginalne pod względem skali społecznego oddziaływania. Rzutuje to nie tylko na atrakcyjność jego praktyk, ale również na kwestię nośności eksponowanych w nim treści światopoglądowych. W artykule podjęta została próba ukazania neopoganizmu w szerszej perspektywie historyczno-kulturowej, uwzględniającej tak ogólne zagadnienia jak tożsamość kulturowa czy kultura pamięci. Autor stawia przy tym pytanie, czy neopoganizm, z jego marginalnością i utopijnością, można uznać za zjawisko wpisujące się w problematykę postkolonialną (postzależnościową). Uważa, że w przypadku takich krajów jak Polska neopogański konstruktywizm może być traktowany jako sensowna próba poszerzenia bazy symbolicznych odniesień dla refleksji nad własnym usytuowaniem na osi centrum - peryferie.
\end{abstract}

\begin{abstract}
Tomasz Nakoneczny, NEOPOGANISM AS A POSTCOLONIAL ISSUE. THE POLISH CONTEXT. "PORÓWNANIA" 1 (22), 2018. Vol. XXII, P. 91-106. ISSN 1733-165X. Neopaganism is usually perceived as a marginal phenomenon in terms of the scale of social impact. It not only affects the attractiveness of its practices, but also the question of the load-bearing capacity of the world-outlooks exhibited in it. The article attempts to show neopaganism in a broader historical and cultural perspective, taking into account such general issues as cultural identity or memory culture. The author asks the question whether neo-paganism, with its marginality and utopianism, can be considered as a phenomenon inherent in postcolonial (post-dependence) problems. He believes that in the case of countries such as Poland, neopagan constructivism can be treated as a sensible attempt to broaden the base of symbolic references for reflection about its own location on the center-periphery axis.
\end{abstract}

1 E-mail: tomasz.nakoneczny@wp.pl; tomnak@amu.edu.pl 
Neopoganizm², termin z natury wieloznaczny ${ }^{3}$, postrzegany jest zwykle jako specyficzna odmiana współczesnego folkloru, o dość niejasnej proweniencji i przeznaczeniu, której praktyki, wartości i aspiracje sytuują ją na trudnym do pojęciowego zagospodarowania obszarze pogranicznym między sektami religijnymi a ruchami proekologicznymi. Obraz ten nie powinien jednak przesłaniać możliwości szerszego spojrzenia na działalność neopogan jako na zjawisko funkcjonujące na przecięciu doniosłych i frapujących szlaków dyskursywnych, wśród których znajdują się - co spróbuję dopiero wykazać - badania postkolonialne.

Powody, by neopoganizm sytuować w kontekście tych ostatnich, widoczne są już na pierwszy rzut oka. Mam tu na myśli zwłaszcza wielostronną na gruncie badań postkolonialnych kontestację dziedzictwa chrześcijańskiego, percypowanego głównie - jak się wydaje - przez pryzmat kategorii tożsamości (jako tożsamość obca, narzucona przemocą, a w efekcie - wydziedziczająca). Percepcja chrześcijaństwa jako ideologicznego wehikułu ekspansywnej i aroganckiej cywilizacji, dążącej do podporządkowywania sobie obszarów leżących na jej peryferiach (a później również poza nimi, na odległych krańcach globu), jakkolwiek wykracza poza ramy czasowe zjawiska określanego mianem europejskiego kolonializmu (XVI-XX wiek), zdaje się dobrze pasować do postkolonialnej matrycy pojęciowej, w której wyróżnione miejsce przypada na opozycję centrum - peryferie.

2 Problematyka związana z semantyką terminu „neopoganizm” zasługiwałyby na osobne studium. Jak trafnie, moim zdaniem, zauważa Remigiusz Okraska: „nie mamy do czynienia z naturalnym, organicznym systemem wierzeń, lecz ze zideologizowaną, stworzoną w sposób przynajmniej częściowo sztuczny, doktryną o wtórnym charakterze, z nowoczesnym konstruktem przypominającym ideologie” (Okraska 13). „Najszerszym i najprecyzyjniejszym terminem wydaje się zatem określenie «religie/wspólnoty rekonstrukcjonistyczne», ich celem bowiem jest «twórcze wskrzeszenie» starych wierzeń" (Pasek 8). W niniejszych rozważaniach odwołuję się głównie do polskich doświadczeń i do polskiej terminologii, choć warto pamiętać, że mamy do czynienia: a) ze zjawiskiem uniwersalnym, b) z podobnymi $\mathrm{w}$ odniesieniu do różnych krajów ujęciami definiującymi. Przykładem niech posłuży ujęcie zjawiska rosyjskiego neopoganizmu przez jego wybitnego znawcę Wiktora Sznirelmana: „Pod russkim nieojazyczestwom sledujet ponimat' dwiżenija, stawiaszczije pieried soboj cel skonstruirowat' «istinno russkuju rieligiju», kotoraja połnostju udowletworiała by sowriemiennym potriebnostiam russkogo obszczestwa i russkogo gosudarstwa. Riecz idiet ob obszczenacyonalnoj rieligii, iskusstwiennosozdawajemoj gorodskoj intiełligiencyjej iz fragmientow driewnich dochristianskich łokalnychwierowanij i obriadow s celju «wozrożdienija nacyonalnoj duchownosti». Fakticzeski że sledujet goworit' nie o wozrożdieniirieligii, a o konstruirowanii idieołogiczeskoj osnowy dla nowoj socyalno-politiczeskoj obszcznosti,boleje sootwietstwujuszczej usłowijam modiernizacyi. Pri etom rieligija nieriedko ponimajetsia kak idieołogija" (Sznirelman 12).

3 Posługuję się $\mathrm{w}$ artykule terminem "neopoganizm” zamiast stosowanego zwykle przez samych neopogan "neopogaństwa”, podzielając w tym względzie stanowisko cytowanego wyżej Okraski, który zwraca uwagę na konstruktywistyczny, ideologiczny wymiar zjawiska, przez co jako odpowiedniejszy jawi mu się „neopoganizm”. Zdaniem Macieja Strutyńskiego, rozróżnienie na neopogaństwo i neopoganizm „nie jest konieczne”. Uważa on również, że "granice obu tych pojęć nigdy nie zostały jasno określone" (Strutyński 12). Ogólna skala moich rozważań, a także ich ukierunkowanie na tytułowy problem badawczy (neopoganizm a postkolonializm) upoważniają mnie, jak sądzę, do terminologicznych uproszczeń. $Z$ tego powodu nie przywołuję zagadnienia rodzimowierstwa jako odrębnego segmentu pojęciowego w systematyce neopogańskiej. 
Można powiedzieć, że chrześcijaństwo jest w optyce neopogańskiej niejako skazane na pełnienie roli negatywnego układu odniesienia ${ }^{4}$. I to wcale nie - a w każdym razie nie przede wszystkim - za sprawą swojej charakterystyki światopoglądowej, lecz przez fakt bycia czynnikiem destrukcji w stosunku do dziedzictwa przedchrześcijańskiego, traktowanego tutaj jako rdzenne, autonomiczne, a w ostatecznym rozrachunku bliższe wspólnotowej psyche.

Warto podkreślić, że neopogańskie projekcje chrześcijaństwa nie muszą wiązać się z przypisywaniem temu drugiemu cech stricte religijnego oponenta. Realnie rzecz biorąc, nie ma między chrześcijanami i neopoganami przestrzeni do merytorycznego sporu doktrynalnego, jaka występuje zwykle między dwoma wyznaniami podzielającymi pewien zbiór zasad. I nie chodzi o fakt ignorowania przez Kościoły chrześcijańskie neopoganizmu jako ideowego adwersarza, lecz o to, że najistotniejsze - co widać wyraźnie z punktu widzenia odbiorcy zewnętrznego - różnice zaznaczają się w danym przypadku nie na płaszczyźnie religijnej, lecz ideologicznej. Sumaryczne zestawienie rozmaitych figuracji, przedstawień i przywołań chrześcijaństwa w ramach tekstualności neopogańskiej skłania do wniosku, że chrześcijaństwo funkcjonuje tutaj częściej jako metonimia niszczycielskiej cywilizacji (zależnie od kulturowego usytuowania kontestatora - łacińskiej, zachodniej, bizantyjskiej etc.) bądź jako agens władzy niż jako konkurencyjny system religijny z właściwym mu rozbudowanym komponentem moralnym i teologicznym.

Wydaje się zresztą, choć i to spostrzeżenie wynika z bardzo uogólnionej obserwacji, że dla wielu współczesnych neopogan kontestacja chrześcijaństwa i uosabianej przez nie cywilizacji jest sprawą daleko mniej ważną aniżeli pozytywne treści ich programów, ukierunkowane na (re)konstrukcję dawnych, przedchrześcijańskich wierzeń i obyczajów. Okolicznością ważną, bo rzutującą bezpośrednio na pozycjonowanie ruchów neopogańskich jako marginalnych, jest stylistyka (formy kultu, symbole, obrzędowość etc.), w jakiej te ostatnie do przeszłości nawiązują. Zaryzykowałbym twierdzenie, że stylistyka ta dystansuje wobec neopoganizmu $\mathrm{w}$ większym stopniu aniżeli jego aspekty czysto doktrynalne, takie jak henoteizm czy panteizm.

Paradoksalnie na pozór, czynnikiem najsilniej chyba kształtującym neopogańską percepcję wypartej przez chrześcijaństwo i cywilizację grecko-rzymską autochtonii jest stosunek do cywilizacji współczesnej, a w szczególności do tych jej przejawów, które wydają się interferować z szeroko rozumianą sferą tożsamości kulturowej. Korelacje tego rodzaju trudno uznać za przypadkowe, jeśli weźmiemy

$4 \mathrm{~W}$ praktyce jednak obustronne relacje były, jak zwykle w takich razach, daleko bardziej skomplikowane. „Dostrzeżemy - zauważa Jarosław Tomasiewicz - historyczne procesy obustronnej osmozy: chrześcijaństwo nasiąkało elementami pogańskimi, a religie pogańskie rozwijały się pod wpływem chrześcijaństwa. W tym kontekście nie powinno nas więc dziwić, że kwitnie synkretyzm pogańsko-chrześcijański ("przedchrześcijańskie chrześcijaństwo»), a niektórzy neopoganie deklarują się równocześnie jako chrześcijanie" (Tomasiewicz 345). 
pod uwagę fakt, że dzisiejsi członkowie i sympatycy ruchów neopogańskich rekrutują się na ogół spośród wielkomiejskiej inteligencji. Nie zapuszczając się w meandry dociekań socjologicznych, na które nie wystarczyłoby miejsca w niniejszym szkicu, poprzestańmy na konstatacji, że kwalifikator wielkomiejskiej inteligenckości tłumaczy: a) wagę kwestii tożsamościowej w neopoganizmie (biorąc za punkt odniesienia Baumanowski koncept wspólnoty i jej uwikłania w charakteryzującą kondycję (po)nowoczesną aporię wolności i bezpieczeństwa, w próbach (re)konstruowania wspólnot pogańskich możemy widzieć wyraz tęsknoty za tożsamościową integralnością i stabilizacją w świecie niepewności ${ }^{5}$ ) oraz b) poziom kompetencji kulturowych (inteligenci, według Henryka Domańskiego, „dysponują najwyższym kapitałem kulturowym" (Domański 246)), warunkujących świadome, zaangażowane, wiarygodne i - co w danym przypadku nie najmniej istotne - twórcze konfrontowanie się z problemem samookreślenia światopoglądowego.

Istnieje jeszcze jeden powód, psychologicznie zapewne bardziej zrozumiały dla odbiorcy zewnętrznego, izolacji subkultur neopogańskich. Chodzi o przywołany już wcześniej konstruktywizm neopoganizmu ${ }^{6}$. Dotyczy on nie tylko wymiaru obrzędowego, ale też, co nierównie ważniejsze, światopoglądowego ${ }^{7}$. Brak legitymizacji przez któryś z szeroko akceptowanych systemów logocentrycznych pozbawia wiarygodności aspiracje neopogan do formułowania własnych propozycji ideologicznego samouzasadnienia, a także do odpowiednio mocnego osadzenia w ramach oficjalnej struktury dyskursywnej. Spośród różnych strategii wykluczenia, jakimi dysponuje współczesna kultura, w stosunku do ruchów neopogańskich wybiera ona zwykle obojętną tolerancję. Neopoganie, sytuowani w obrębie wcześniejszych, przednowoczesnych formacji na pozycji wroga publicznego, wobec którego - używając obrazowej terminologii Claude'a Lévi-Straussa (Lévi-Strauss) - potrafiono

5 Próby realizacji wspólnotowych utopii natrafiają jednak w ponowoczesnym świecie na fundamentalne przeciwności. „Rzeczywiście istniejąca wspólnota będzie nie tyle wyspą «naturalnego rozumienia», «ciepłym kręgiem», gdzie moglibyśmy odłożyć swoją broń i zaprzestać walki, ile czymś na kształt oblężonej fortecy nieustannie bombardowanej przez (często niewidzialnych) wrogów zewnętrznych i raz po raz rozdzieranej przez wewnętrzną niezgodę" (Bauman 23).

6 Konstruktywizm ten trudno uznać za ekspresję określonej postawy światopoglądowej, inaczej zatem niż dzieje się w przypadku klasycznie modernistycznych tworów kultury. Wynika on po prostu z zasadniczego braku źródeł pisanych. „Badaczowi prasłowiańskich wierzeń towarzyszy często uczucie bezradności. Wiarygodne źródła historyczne, które prezentowałyby rodzimą mitologię w sposób przejrzysty i całościowy, nie istnieją. Rodzi i historycy mogą jedynie marzyć o takich zabytkach literackich, jakimi są w przypadku religii germańskiej Edda, a dla religii praindyjskiej Rygweda" (Zielina 5).

7 Ow konstruktywistyczny aspekt neopogaństwa widoczny jest chyba najbardziej w organizacjach rodzimowierczych, ale nie stanowi on tam problemu związanego z wiarygodnością i legitymnością, jak ma to miejsce w przypadku obserwatorów zewnętrznych. „Niedostatek źródeł historycznych dotyczących religijności i duchowości dawnych Słowian nie jest jednak problemem dla współczesnych rodzimowierców, którzy twierdzą, iż religia «musi być żywa» i na bieżąco uzupełniają białe plamy w wiedzy historyczno-religioznawczej treściami kulturowymi wytworzonymi współcześnie" (Pankalla, Kośnik 40). 
stosować tylko jedną z dwóch strategii - antropofagii (inkluzji) i antropoemii (ekskluzji) - dzisiaj zdolni są do budzenia zainteresowania głównie jako obiekt badań naukowych.

Oczywiście wspomniane względy nie muszą przesądzać sprawy, którą pragnę uczynić motywem przewodnim niniejszych rozważań, a mianowicie możliwości przypisania neopoganizmu do badań postkolonialnych. Elementarne pytanie, jakie się w związku z tym nasuwa, brzmi następująco: jaką - i czy w ogóle jakąś - wartość eksplikatywną może mieć zestawianie projektów, z których jeden (neopoganizm) realizuje się $\mathrm{w}$ absolutnie marginalnym zbiorze praktyk symbolicznych, a drugi (postcolonial studies) w diagnozowaniu zjawisk społecznych dużej skali? Odpowiedź wydaje mi się oczywista: warunkiem dopuszczalności takich zestawień jest wyprowadzenie neopoganizmu z opłotków socjologizacji i umieszczenie go w szerokim kontekście kulturowym po to, by spojrzeć nań jako na: a) ogniwo alternatywnej narracji tożsamościowej, b) jedno ze znamion kryzysu w dominującym dotychczas paradygmacie tożsamościowym, c) przyczynek do zmodernizowania aparatury projekcyjnej, przy użyciu której konstruowany jest obraz kształtowania się tegoż paradygmatu $\mathrm{w}$ wymiarze historycznym.

$\mathrm{Na}$ ile studia postkolonialne ze swoim potencjałem hermeneutycznym mogłyby przyczynić się do krytycznej i ożywczej rekontekstualizacji dziedzictwa prasłowiańskiego/przedchrześcijańskiego? Nie tylko w trybie uzupełnień interpretacyjnych (wypełnianie tekstualnych luk) czy dekonstrukcji (ujawnianie mechanizmów dominacji i subwersji), ale również - a biorąc pod uwagę interwencyjny etos postkolonializmu, przede wszystkim - w trybie konfrontacji. Bazą konfrontacji musiałaby być wizja centro-peryferyjnych interakcji, gdzie centrum reprezentowałaby cywilizacja łacińska, a peryferie pogańska prasłowiańszczyzna i jej wieloraka spuścizna. Celem natomiast takiej konfrontacji byłoby poszerzenie pola rodzimego dyskursu tożsamościowego.

Oczywiście, perswazyjna moc postkolonializmu, uzależniona zawsze od idiosynkratycznej sugestywności jego twórców, musiałaby doznać tutaj dodatkowych ograniczeń. Pierwsze z nich wynika stąd, że przedmiot interwencji, czyli prasłowiańska (pogańska) tekstualność, skromna (mam tu na myśli trywialny, lecz dojmujący fakt szczupłości źródeł historycznych), a w swoich późniejszych - w czasach hegemonii chrześcijaństwa - redeskrypcjach notorycznie desemantyzowana, została w ostatecznym rozrachunku bardzo wyraźnie oddzielona od żywych, wartościotwórczych obszarów dyskursywności. Próby animowania poganizmu jako czynnika aksjologicznego poza tekstualnością artystyczną, w obrębie której zresztą najczęściej sprowadza się on do funkcji konstruktu sztafażowego, wydają się skazane na marginalizację, w pewnych zaś szczególnych przypadkach (neopoganizm, postkolonializm) - na jawną ideologizację.

Ostatnia konstatacja nie jest zarzutem, lecz wskazaniem na potencjalne źródło mocy: dyskursywną doniosłość może (neo)poganizmowi zapewnić fortunny splot 
uwarunkowań społecznych (tożsamościowy ferment, jaki wytwarza stan napięcia między tradycjonalizmem a nowoczesnością) oraz nonkonformistycznej, atrakcyjnej intelektualnie idiosynkratyczności tych, którzy dokonują projekcji dziedzictwa prasłowiańskiego/pogańskiego jako ważnego układu odniesienia. Trzeba jednak sprawiedliwie przyznać, że mainstream polskiego dyskursu postkolonialnego nie przejawia w tej mierze żywszego zainteresowania (poza wyjątkiem, o którym za chwilę), koncentrując się na tematach „bezpiecznych”, to znaczy wpisujących się $\mathrm{w}$ ramy percepcyjne i metodologiczne postkolonializmu zachodniego.

Moja wiara w możliwość odegrania tu znacznej roli przez "silnych poetów” (strong poets) dyskursu tożsamościowego, literatów, publicystów, myślicieli, badaczy postkolonialnych, współistnieje z przekonaniem, że neo(pogańskie) formy narratywizacji rzeczywistości nie zostały u nas nigdy potraktowane wystarczająco poważnie, ergo nie został wykorzystany ich dyskursywny potencjał. Neopoganizm, podobnie jak nawiązujące do niego style myślenia, nie obudziły nigdy zainteresowania świata zewnętrznego w stopniu porównywalnym do innych formacji mniejszościowych: genderowych, etnicznych, klasowych etc.

Postkolonializm jako orientacja światopoglądowa (a nie tylko zbiór dyrektyw badawczych) ma tutaj, jak się wydaje, szczególnie dużo do odrobienia. W odróżnieniu od dyskursów opowiadających się za redukcją podmiotowej idiosynkratyczności (strukturalizm, fenomenologia) postkolonializm, podobnie zresztą jak niemal cały kulturalistyczny nurt współczesnej humanistyki, z którego się on wywodzi i którego pozostaje częścią, na ogół nie przeciwstawia się posądzeniom o perspektywizm czy idiosynkratyczność, które uwidaczniają się za sprawą jego oczywistych związków z poststrukturalizmem. Zachęca to do spojrzenia na potencjał eksplanacyjny studiów postkolonialnych sub specie ich etycznej wrażliwości i zaprzęgniętego w jej służbę intelektualnego krytycyzmu, które na ołtarzu godności, empatii i sprawiedliwości gotowe są poświęcić ambicje ustanowienia "twardej metodologii". Zresztą trudność w utrzymaniu dyskursu postkolonialnego w ryzach naukowości widoczna jest już na poziomie bazowym. Jego rdzeń pojęciowy (kolonializm) wraz $\mathrm{z}$ inherentną dlań binarnością (centrum - peryferie), wykazuje tendencję, słabo przy tym kontrolowaną, do wielokierunkowej radiacji (nowe tematy badawcze, nowe obszary geopolityczno-kulturowe etc. $)^{8}$. Dzieje się tak prawdopodobnie za sprawą coraz większej wagi, jaka przywiązywana jest do moralnych aspektów kolonializmu, a także za sprawą jego głębokich uwikłań psychologicznych.

Znaczny rozrzut tematyki podejmowanej na rodzimym, polskim, gruncie (literatura dziecięca, Słowiańszczyzna, sarmatyzm, romantyzm, mesjanizm, zabory, Kresy, PRL, literatura współczesna etc.) znamionuje nie tylko żywiołowość pionier-

8 Modelowego przykładu wspomnianej radiacji dostarczają środkowo-wschodnioeuropejskie studia postkolonialne aplikowane na grunt zupełnie odmienny od tego, który zagospodarowywali światowi pionierzy postcolonial studies. 
skiego ducha, ale również naturalną niejako, związaną z przedmiotem i charakterem badań ekspansywność. Niektóre z tych wątków wykazują się problematyczną użytecznością dla badań postkolonialnych (Słowiańszczyzna, o której za chwilę), inne z kolei owocują wciąż nowymi ujęciami (Kresy) i wzbogacają dyskurs o nowe kategorie pojęciowe (np. melancholia). Od pewnego czasu mamy do czynienia z próbami daleko idącego rozciągnięcia granic czasowych dyskursywnej bazy polskiego postkolonializmu (Sowa) oraz z kontrpróbami utrzymania jej w ryzach zasadniczej zgodności z metodologią anglojęzycznej klasyki (Skórczewski 2013).

Nie jest chyba sprawą przypadku, że spór o zakres przedmiotowo-problemowy postkolonializmu nakłada się na wyrazisty podział ideowy polskiej inteligencji (choć partycypują $\mathrm{w}$ nim również i inne grupy społeczne) na dwa przeciwstawne obozy, które umownie i upraszczając można określić mianem „konserwatywnego" i „liberalnego". Wydaje się, że identyfikowanie polskiej specyfiki (post)kolonialnej z szerszymi kontekstami historycznymi (związki z cywilizacją rzymską, chrystianizacja, wczesnonowożytne antecedencje kapitalizmu), charakteryzujące ogląd „liberalny" (Sowa), wiąże się z większym dystansem wobec dominującego paradygmatu tożsamościowego (Polak-katolik) oraz z większą otwartością na autokrytycyzm i na rekonfiguracje $w$ obrębie systemu zbiorowego samopostrzegania, podczas gdy opcję "konserwatywną" motywuje, oprócz przywiązania do wspomnianego paradygmatu, chęć "ocalenia" przed potencjalną destrukcją niektórych mitów i wyobrażeń życia zbiorowego (związanych na przykład z katolicyzmem, aksjologią sarmatyzmu czy etosem niepodległościowym). Jest to, rzecz jasna, uproszczony obraz postaw, nieoddający złożoności zjawiska, a przez to wymagający weryfikacji $\mathrm{w}$ ramach innego studium.

Efektywność podejścia postkolonialnego zależy w rozpatrywanym tutaj przypadku nie tylko od rozstrzygnięć cząstkowych, na przykład dotyczących substratu czasowego. Ważne jest zwłaszcza to, czy - jako się rzekło - zechcemy spojrzeć na (neo)poganizm jako na zjawisko socjologiczne, a więc marginalne i pozbawione szerszego rezonansu, czy też jako na czynnik dyskursywny funkcjonalizujący pewną ważną część debaty tożsamościowej, a zarazem otwierający dla refleksji wielopoziomową perspektywę historyczno-kulturową. W tym drugim przypadku chodziłoby niewątpliwie o dowartościowanie ukrytych przez wieki w rozmaitych przejawach kultury ludowej, w formach politycznej samoorganizacji (vide demokracja szlachecka), a także w literaturze i sztuce rudymentów szeroko rozumianej przeszłości prasłowiańskiej. Epifenomenalną korzyścią byłoby tu wzbogacenie obrazu historii Polski, umożliwienie spojrzenia na nią z nowej, inspirującej perspektywy.

Czynnikiem sprzyjającym takiemu podejściu byłoby operowanie bardziej zróżnicowaną niż dotąd skalą kontekstualną. Mam na myśli potrzebę wyodrębnienia nowych, obok Zachodu i Wschodu, członów europejskich relacji centro-peryferyjnych. Polegałoby ono na wyeksponowaniu i zdefiniowaniu specyfiki doświadczeń historycznych tych obszarów (członów). Nie wykluczałoby to ujmowania 
rzeczonej specyfiki w kategoriach organicznej heterogeniczności (mozaikowości, policentryczności $)^{9}$. Tak właśnie musiałoby być $\mathrm{w}$ przypadku Słowiańszczyzny niejednokrotnie już, zwłaszcza w XIX wieku (romantyzm, panslawizm), ale również wcześniej (Herder), postrzeganej jako pewna duchowa całość ufundowana na wspólnocie pochodzenia i języka.

Przechodzimy w ten sposób do Słowiańszczyzny jako wykładnika rodzimości utożsamianej najczęściej z kulturą agrarną, głębokim związkiem z Naturą, z egalitaryzmem ${ }^{10}$ i pacyfizmem przeciwstawianym, niekiedy na wyrost, zaborczej ekspansywności niemczyzny, jej zamiłowaniu do hierarchicznego porządku społecznego oraz jej kultowi siły. W roli negatywnego układu odniesienia bywa przywoływany tutaj również Zachód in toto jako uosobienie bezdusznej, materialistycznej cywilizacji tudzież jako rozsadnik zepsucia moralnego, w stosunku do których Słowiańszczyzna reprezentuje antytetyczny, na wskroś pozytywny świat wartości.

W rezultacie przyjęcia powyższej optyki problem kolonizacji niełacińskiej Europy znalazłby się $\mathrm{w}$ nierównie pojemniejszej perspektywie interpretacyjnej niż ta, którą zdefiniowali na użytek swoich domen badawczych klasycy postcolonial studies. Ta nowa perspektywa obejmowałaby procesy społeczne i cywilizacyjne biorące początek co najmniej w chwili porzucenia przez władców Europy Wschodniej i Środkowo-Wschodniej starych, autochtonicznych religii i otwarcia ich krajów na chrystianizację. Mowa o, co warto podkreślić, procesach uwikłanych w dramatyczne okoliczności. Dramatyzm ów jednak ulega od początku asonoryzacji na gruncie kultury oficjalnej. Dokonuje się również racjonalizacja zjawisk i procesów będących, w świetle dzisiejszych pojęć, mieszaniną eksterminacji i przemocy kulturowej. W dominujących - statystycznie i symbolicznie - ujęciach historiograficznych chrystianizacja przedstawiana jest $\mathrm{z}$ reguły $\mathrm{w}$ kategoriach pragmatyczno-darwinistycznych jako przejście z niższej formacji społeczno-kulturowej do wyższej, stwarzającej możliwość lepszego przystosowania się do realiów politycznych ówczesnego świata.

9 Chodziłoby przy tym między innymi o odejście od zwyczaju traktowania Zachodu jako niezbędnego układu odniesienia podczas prób eksplanacji „osobliwości” Europy Środkowej czy też Środkowo-Wschodniej. Przykładem powstających na tym tle nadużyć niech będzie porównywanie projekcji wolnościowych o tak różnych charakterystykach ideologicznych jak polski sarmatyzm i oświeceniowy republikanizm. Miałoby to sens jedynie wówczas, gdybyśmy chcieli potraktować oba te projekty jako odpowiedzi na odmienne zestawy wyzwań, jakie przed społeczeństwami danego czasu stawiała rzeczywistość tak ludzka, jak przyrodnicza, nie zaś jako na strukturę komparatywną, w której jeden człon (comparans) jest modelem dla drugiego (comparandum).

10 „Słowianie przynieśli ze sobą całą kulturę Arjów z mentalnością typowo agrarną i tak jak do Etrusków, pasowało do nich określenie paganos, zarówno w odniesieniu do religii, jak i filozofii życia. Podstawą agrarnej mentalności Słowian jest ich naturalny język, w którym aparat pojęciowy nadaje światu strukturę różnorodnego, ale jednolitego w swych podstawowych właściwościach bytu, nie oddzielając człowieka od przyrody i kosmosu, czyniąc go jednocześnie odpowiedzialnym za całość bytu. Podobnie też nasz język determinuje egalitaryzm i sieciowość jako odczucie prawidłowego ładu społecznego" (Słowiński 11). 
Propozycja wspólnego rozpatrywania zagadnień tożsamości i wydziedziczenia (z tradycji prasłowiańskiej) nie rozbrzmiewa w tekstualnej próżni. Mamy w dorobku rodzimej humanistyki prace zorientowane na rekonstrukcję przedchrześcijańskiego obrazu świata na czele z niezmiernie popularną w swoim czasie Mitologia Stowian Aleksandra Gieysztora. Walor poznawczy tej ostatniej jest trudny do przecenienia: dysponując relatywnie szczupłą podstawą źródłową, autor roztacza sugestywny i frapujący obraz wierzeń pogańskich, a co nie mniej istotne, uzmysławia, z jak wielką skalą utraty/destrukcji mamy tutaj do czynienia. Równocześnie jednak występuje w rzeczonym dorobku Niesamowita Słowiańszczyzna Marii Janion, pozycja, którą możemy potraktować jako podstawowe odniesienie dla wszelkich późniejszych prób opisywania polskiej tożsamości przez pryzmat jej związków, uchwytnych bądź domniemanych, z rodzimą, przedchrześcijańską kulturą.

Chciałbym przez chwilę skupić się na książce Janion w kontekście bardzo znamiennej polemiki, z jaką wystąpił wobec niej Dariusz Skórczewski w artykule Trudności z tożsamością. Na marginesie Niesamowitej Słowańszczyzny ${ }^{11}$. Polemiki życzliwe i nastawione na przedmiot sporu (a z taką mamy tu niewątpliwie do czynienia), a więc unikające argumentacji ad personam, mają zwykle to do siebie, że uwypuklają i problematyzują ważne kwestie natury rzeczowej. Jednocześnie, dzięki merytorycznemu zagęszczeniu, stwarzają odbiorcy zewnętrznemu sposobność do wychwycenia aspektów sporu z różnych względów pominiętych przez jego uczestników. Tak właśnie jest $\mathrm{w}$ tym przypadku.

Osią niezgody jest to, co Skórczewski określa jako rozumienie „istoty zjawiska skolonizowania w kontekście polskiego doświadczenia historycznego" (Skórczewski 2013: 409), a co autorka Niesamowitej Stowiańszczyzny wiąże ze znalezieniem się ziem polskich w orbicie wpływów cywilizacji łacińskiej i wynikającym stąd odcięciem od własnej, pogańskiej/prasłowiańskiej tradycji:

Późniejsza orientalizacja Polski i jej mieszkańców w dyskursach zachodnioeuropejskich, poczynając od Oświecenia, miałaby być, zdaniem Janion, przedłużeniem tej pogardy, jaką zlatynizowana Europa rzekomo od początku żywiła dla organizmów politycznych we wschodniej części kontynentu jako tworów powstałych później i przez to drugorzędnych, upośledzonych, gorszych (Skórczewski 2013: 409).

W istocie zarzuty Skórczewskiego można sprowadzić do dwóch kwestii: a) znacznego i nieuprawnionego, jego zdaniem, w świetle faktów historycznych przesunięcia "dolnej granicy” czasowej polskiego skolonizowania (wejścia Polski w relację zależności od zewnętrznego centrum ze wszystkimi tego, ujemnymi dla

11 Zob. Skórczewski 2008. Tekst ten pojawia się również, pod zmienionym tytułem, w książce tegoż autora pt. Teoria - literatura - dyskurs. Pejzaż postkolonialny, na którą powołuję się w niniejszych rozważaniach. 
polskiego etnosu, konsekwencjami). Zdaniem lubelskiego badacza prowadzi to do rozmycia semantycznego pojęcia kolonializmu i osłabienia metodologicznego studiów postkolonialnych; on sam opowiada się, za Edwardem Saidem, za uznaniem wieku XIX za początek ery kolonialnej, oraz b) zbyt swobodnego operowania kategorią „Słowiańszczyzny” (cudzysłów wynika z operacjonalizacji terminu) jako zawierającą konotacje ideologiczne całkowicie sprzeczne z intencjami autorki: maskuje ona bowiem cele dyskursywne przyświecające niegdysiejszym kolonizatorom, niemieckiemu i rosyjskiemu (później sowieckiemu). Mamy zatem z jednej strony niemiecki (a w istocie pruski) koncept jednego narodu słowiańskiego, unieważniający arogancko podziały etniczno-kulturowe i całą w ogóle specyfikę historyczną Europy Środkowo-Wschodniej, z drugiej zaś narratywizowany na różne sposoby przez rosyjską myśl polityczną mit słowiańskiej jedności (panslawizm).

Oba zarzuty można uznać za równie dyskusyjne co tezy Janion. Drugi z nich, dotyczący Słowiańszczyzny, choć wydaje się zasadniczo słuszny w kontekście XIX- i XX-wiecznych słowników politycznych, wypada chyba uznać za obciążony nadmiernym formalizmem $\mathrm{w}$ odniesieniu do rozważań nad traumą kulturowego/tożsamościowego wydziedziczenia. Nie sposób zaprzeczyć, że określenie Słowiańszczyzna jest $\mathrm{w}$ znacznej mierze synonimiczne względem takich terminów jak Europa Środkowa czy Europa Środkowo-Wschodnia i że nie zawiera w danym przypadku ściśle rasowej czy językowej konotacji. Znacznie sensowniej byłoby przyjać, że Słowiańszczyzna to - w świetle rozważań nad wewnątrzeuropejskimi relacjami władzy i przemocy - domena peryferyjności, którą wyróżnia między innymi relatywnie późne włączenie $\mathrm{w}$ orbitę chrześcijaństwa, zależnościowe usytuowanie względem Zachodu, świadomość odmienności własnych korzeni kulturowych etc. A co za tym idzie, lepiej przyjąć, że użyteczność dyskursywna tej kategorii wynika z ulokowania jej w sferze symbolicznej, nie zaś empirycznej.

Dużo ważniejszy wydaje mi się zarzut pierwszy, dotyczący pozornie tylko zagadnienia czysto metodologicznego, jakim jest dyskusyjność ram chronologicznych i problemowych przedmiotu badań. W rzeczywistości równie ważny jest tutaj wymiar podmiotowy. Chodzi o zdolność polskich postkolonialistów do wywikływania się z paradygmatycznych zależności narzuconych przez narracje zewnętrzne i do wypracowywania własnych niezależnych stanowisk. To, co Skórczewski zarzuca Janion: wpisywanie się jej konceptu Słowiańszczyzny w orientalizujący dyskurs imperialny, dotyczy w równej mierze jego samego. $\mathrm{W}$ jednym $\mathrm{z}$ finalnych akapitów artykułu lubelskiego badacza natrafiamy na następujący passus:

Profesor Janion opowiada się za taką interpretacją historii Polski, w której przyjęcie chrześcijaństwa pojmowane jest $\mathrm{w}$ kategoriach gwałtu na pierwotnym, pogańskim organizmie społecznym, nie zaś jako suwerenny wybór polityczny i religijny, owocujący wejściem do wspólnoty niepodległych i równoprawnych państw (Skórczewski 2013: 422). 
Nie ma w istocie merytorycznego powodu, by arbitralne stwierdzenia o „suwerennym wyborze politycznym" owocującym wejściem do grona "równoprawnych państw” przedkładać nad podobnie arbitralną kategorię "gwałtu”. „Podobnie” nie znaczy jednak „równie”: mamy bowiem więcej powodów, by relację świata chrześcijańskiego i pogańskiego postrzegać w kategoriach przemocy i dominacji, niż by w obliczonych na przyjęcie chrztu działaniach Mieszka I i jego najbliższego otoczenia dopatrywać się jakichś szczególnych oznak politycznej suwerenności. Znając realia ówczesnej polityki międzynarodowej, trudno sobie wyobrazić, by pierwszy historyczny władca ziem polskich decydował się na wybór nowej religii, nie odczuwając presji geostrategicznej ze strony cesarstwa ottońskiego. „Nie ulega wątpliwości - zauważa historyk, Przemysław Urbańczyk - że szerzenie nowej religii sprawiało naszemu pierwszemu władcy wyraźne trudności lub też niezbyt się w to angażował" (Urbańczyk 12).

Warto zwrócić uwagę na konwencjonalność opinii o jednoznacznie pozytywnym znaczeniu przyjęcia chrześcijaństwa, pobrzmiewającą nawet w zniuansowanych komentarzach historyków współczesnych:

Przyjęcie chrztu wprowadziło Polan do grona ludów cywilizowanych i dawało formalnie równoprawny status $\mathrm{w}$ ramach wspólnoty chrześcijańskiej, obejmującej w $\mathrm{X}$ w. rozwinięte kraje Europy. Organizacja kościelna stanowiła istotny, niezależny od powiązań z dawnym systemem plemiennym czynnik, na którym władza mogła oprzeć działalność. [...] Przyjęcie chrześcijaństwa sprzyjało tym, którzy zrywając ze starym systemem życia szukali nowych wzorów, nowych ideologii. System społeczny zachodniej czy południowej Europy, odpowiadał potrzebom rodzącej się w Polsce grupy możnych (Samsonowicz 32).

Podobnym analizom można by zwykle zarzucić zupełny brak zainteresowania lub niewystarczające - $\mathrm{w}$ perspektywie dzisiejszej wrażliwości - zainteresowanie "drugą stroną medalu": interesami i położeniem tych, dla których nowy system społeczny stanowił źródło zagrożenia. Oczywiście, istniejąca podstawa źródłowa niejako wymusza koncentrację na punkcie widzenia ówczesnego establishmentu, jednak dla badacza postkolonialnego powinno być oczywiste, że aparat poznawczy uprawianej przez niego dyscypliny zaprogramowany jest na wypełnianie luk w standardowych modelach oglądu naukowego, że ewentualny zarzut pewnej ekstrawagancji interpretacyjnej, na jaki jest on narażony ze strony środowisk o tradycyjnych orientacjach badawczych, stanowi nieuchronną cenę wnoszonej przez niego do własnych badań wrażliwości moralnej. Wrażliwość tę spotykamy chyba częściej w popularnych ujęciach historii, jak w tym oto fragmencie opowieści o podboju Połabia: 
Agresywna ekspansja Niemców na wschód od Łaby, wdrażana pod kierownictwem świeckich i duchownych możnowładców z germańskiego plemienia Sasów [...], trafiła jednak na zdecydowany opór wolnej ludności słowiańskiej, przeciwnej nieludzkiemu ujarzmianiu i chrystianizacji w niemieckim stylu, która wolała zginąć z bronią w ręku, niż dać się bezwolnie unicestwić fizycznie i duchowo (Bartkowski 7).

Niebezpieczeństwa związane z ryzykiem nadinterpretacji czają się, naturalnie, po obu stronach: i po stronie instytucjonalnej nauki, i po stronie tych, którzy skłonni są konfrontować się z jej narracjami. Często popełnianym nadużyciem wśród tych drugich jest aprioryczne założenie istnienia trwałych dyspozycji mentalnych (duchowych), mających świadczyć o zasadniczej ciągłości między współczesnymi kulturami narodowymi a poprzedzającymi je kulturami plemiennymi. Zdzisław Słowiński w artykule Neopogaństwo polskie w świetle systemowej teorii kultury pisze o agrarnej mentalności Słowian, przeciwstawiając ją chrześcijaństwu oraz, jak to określa, koczowniczemu światu wartości Zachodu.

Tej mentalności - zdaniem Słowińskiego - nie naruszyło przyjęcie w X w. chrześcijaństwa, gdyż w jego samych założeniach były odniesienia metafizyczne, a więc odniesienia do świata dla Słowian niezrozumiałego i przyjmowanego z nieufnością. W ich języku i świadomości wszelkie odniesienia do świata przyrody, życia człowieka i społeczeństwa pozostały nienaruszone w swojej agrarnej treści. Średniowiecznego i renesansowego Kościoła nie interesowała zresztą mentalność ludów płacących świętopietrze, tylko dobre stosunki z dworami władców (Słowiński 11).

Wartość tego rodzaju stwierdzeń polega, jak się wydaje, na zdolności do ożywiania idei i tematów istotnych dla danej zbiorowości. W tym przypadku chodzi o wspólnotę neopogańską, której autor powyższych słów jest przedstawicielem. Ale wydźwięk wypowiedzi jest szerszy i zachęca do postawienia pytania o ewentualne granice, do jakich możemy się posunąć w czynieniu użytku z przeszłości, i o skutki, jakie może za sobą pociagnąć przekraczanie tych granic. Myślę, że jedną z miar dopuszczalności pozostaje $\mathrm{w}$ tym względzie umiejętność wchodzenia $\mathrm{w}$ autentycznie dialogiczne (żywe, twórcze, inspirujące) formy relacji z narracjami przeszłości, co zakłada między innymi pewne rozluźnienie rygorów narzucanych przez kultywowany wciąż w niektórych środowiskach badawczych postulat „obiektywnej prawdy”. Do rzeczników takiego liberalizującego sposobu myślenia należy niewątpliwie Hayden White. Jednym ze znaków rozpoznawczych stylu myślenia amerykańskiego badacza jest nadawanie narracjom (o) przeszłości statusu form dyskursywnych, co sprawia, że narracje te przestają być tylko bytami intelligibilnymi, a zaczynają przemawiać do woli i wyobraźni. Ujawnia to ich potencjalnie formacyjną (tożsamościotwórczą) rolę. White pisze: 
Jeżeli historia - badanie przeszłości, ludzkiej przeszłości, badanie res gestae czy „rzeczy dokonanych" niż reakcji i pasywnych odpowiedzi na działania transcendentalnych i uniwersalnych sił - jeżeli tak rozumiana historia ma wartość, to przejawia się ona w wysiłku pokazania, zamanifestowania i przedstawienia rzeczy przeszłych tak, jakby były one w pewien sposób żywe; tak, jakby ich opowiadane fabuły były nadal niezakończone; byśmy, żyjąc obecnie, mogli odczuwać empatię z tymi, którzy już odeszli, tak, by namysł na temat ich przypadków nas wzbogacał (elevated). Takie podejście domaga się bardziej literackiego niż naukowego traktowania pisarstwa historycznego; nawet takiego pisarstwa, które podaje się za naukowe i często osiąga rodzaj naukowości, z definicji rezygnującej z jakichkolwiek subiektywnych wyrażeń i negującej jakiekolwiek wartości inne niż prawda (White 14).

Powody, dla których z polskiej debaty postkolonialnej wyłącza się pełną przemocy, uprzedzeń i niezrozumienia historię relacji chrześcijaństwa i rodzimego pogaństwa, nie wydają się intelektualnie przekonujące ani moralnie uczciwe. Mają jednak, trzeba przyznać, swoją wagę kulturową i emocjonalną. O tym, z jak bardzo zmanipulowanym dyskursywnie wymiarem rodzimych dziejów mamy tu do czynienia, świadczy stosunek elit reprezentujących kulturowy mainstream do tak zwanej kultury ludowej. Wiemy, że ta ostatnia pod niejednym względem stanowi swoiste przedłużenie kultury przedchrześcijańskiej. Tymczasem dominującym obrazem, jaki ukształtowała w ciągu wieków kultura oficjalna, jest utopia „wsi spokojnej, wsi wesołej”, gdzie wieś jawi się jako depozytariuszka rdzennej, autentycznej wiary (chrześcijańskiej) i nieskażonej przez wrogi świat zewnętrzny (lub skażonej tylko częściowo i odwracalnie) moralności. Tymczasem, jak przekonuje nas współczesna historiografia, chrystianizacja - $w$ wymiarze organizacyjnym - wsi polskiej dopełniła się ostatecznie w XV wieku, ponieważ dopiero wtedy stało się możliwe pełne opanowanie ziem przez Kościół dzięki odpowiednio gęstej sieci parafii, a więc kilkaset lat po chrzcie Mieszka. Wiemy jednak skądinąd, że pełne podporządkowanie doktrynie nie zostało osiągnięte nigdy: wyraźne echa pogańskiej przeszłości, sygnalizujące pęknięcia w chrześcijańskim uniwersum, występują w polskim myśleniu i polskich obyczajach stale.

Ograniczanie ram czasowych i problemowych polskich badań postkolonialnych do standardów wyznaczonych przez odmiennie uwarunkowane (instytucjonalnie, historycznie, kulturowo etc.) kręgi badawcze wydaje mi się przejawem nadmiernej i niepotrzebnej ostrożności. Utożsamianie, za Saidem, pola badawczego postcolonial studies z czasokresem, którego dolną granicą miałby być wiek XIX, można porównać do metody pracy detektywa, który za przedmiot śledztwa postanowił obrać wyłącznie okoliczności bezpośrednio związane z przestępstwem. Jeśli dzieje formowania się tożsamości kulturowych rozumiemy jako ciąg komplementarnych, warunkujących się nawzajem procesów i zdarzeń, nie możemy zamykać oczu na fakt, że nasza poświadczona źródłowo historia bierze początek z głębokiego kon- 
fliktu dwóch form tożsamości: tej narzuconej wskutek arbitralnej decyzji ośrodka władzy oraz tej ukształtowanej spontanicznie w ciągu niedającego się zmierzyć czasu przedhistorycznego.

Istnieją poważne, prawdopodobnie nieusuwalne przeszkody na drodze do kanonizacji neopoganizmu jako „normalnego" projektu tożsamościowego, zdolnego do konkurowania z projektami silnie zakorzenionymi w świadomości współczesnych Polaków (katolickim, europejskim). Część związanych z tym ograniczeń dzieli on z innymi ruchami mniejszościowymi (ezoteryczność, dyskursywna i organizacyjna dyspersja, brak szerszego zaplecza społecznego). Niektóre jednak stanowią o jego niepowtarzalności: mam tu na myśli zwłaszcza fakt, że nawiązuje do kanonu dawno i skutecznie poddanego dekanonizacji.

Jaka zatem rola miałaby przypaść $\mathrm{w}$ udziale dyskursom usiłującym $\mathrm{w}$ tak niesprzyjających warunkach rewitalizować kulturę prapolską? Czy nie mamy tu do czynienia z przypadkiem podobnym, choć z praktycznego punktu widzenia jeszcze gorzej rokującym, prób wskrzeszania sarmatyzmu w roli skarbnicy swojskości czy też - $\mathrm{w}$ bardziej radykalnym wariancie $-\mathrm{w}$ roli oręża walki obliczonej na przywracanie narodowej godności? Sądzę, że istnieją co najmniej trzy powody, dla których polskie badania postkolonialne nie powinny lekceważyć impulsów/inspiracji intelektualnych płynących ze strony szeroko rozumianego dyskursu neopogańskiego.

Uwzględnienie go po pierwsze umożliwia poszerzenie refleksyjnego pola nad rodzimą peryferyjnością, wykreślając dlań bardziej realistyczny kontur czasowo-problemowy. Po drugie, różnicuje i zarazem problematyzuje obraz relacji kultury oficjalnej i ludowej (rozumianej tu jako nosicielka tradycji pogańskich) utrwalany w polskiej literaturze, myśli politycznej, a także w polskim dyskursie religijnym. Po trzecie wreszcie, a korzyść to nie najmniejsza, wyczula na głos kulturowej Nieobecności. Nie możemy zapominać, że składające się na naszą tożsamość kulturową historie partykularne (lokalne, etniczne, mniejszościowe) to również pełen dramatyzmu zapis zanikających tradycji. Te „zniknięcia” mają zwykle kolosalny ciężar moralny, a stoją za nimi mechanizmy sprawcze, które kultura oficjalna nierzadko zasłania frazesem bądź całkowicie przemilcza. Współcześnie najbardziej krzycząca tak moralnie, jak i społecznie trauma nieobecności związana jest z polskimi Żydami. W skali naszych dziejów państwowych mamy jednak do czynienia z jeszcze inną przerażającą zagładą (choć oczywiście nie sposób czynić tu jakichkolwiek sensownych paraleli), o którą niemal nikt się dziś nie upomina: unicestwieniem - podczas krwawo tłumionych „powstań ludowych”, ekspedycji karnych, akcji niszczenia miejsc kultu etc. - nigdy niepoliczonej liczby wyznawców religii prasłowiańskiej. Fakt niemal całkowitego wyparcia tego świata ze świadomości narodu, a także to, że kultura pogańska okazała się - w darwinowskich kategoriach - gorzej przystosowana do realiów średniowiecznej polityki, zaś jej panteon bogów jawi nam się dziś jako część zupełnie nieprzekonującej opowieści na temat świata, nie upoważnia nas do jej lekceważenia. 
Neopoganizm i wyrastające zeń praktyki symboliczne możemy, rzecz jasna, traktować jako rodzaj skansenu. Pozostanie on wówczas częścią kultury pamięci, w obrębie której jego znaczenie może rosnąć lub maleć zależnie od skali społecznego zapotrzebowania na generowane przezeń wartości. Lokując jednak ten dyskurs w kontekście szerszym, wyznaczanym przez wielowiekowy proces kształtowania się tożsamości zbiorowej Polaków, nie sposób przeoczyć, że reprezentuje on źródłowy konflikt dwóch tożsamościotwórczych porządków, z których jeden, pogaństwo, bezapelacyjnie przegrał. Utrzymał się jednak przy życiu $\mathrm{w}$ pewnych obszarach kultury, przyjmując mimowolnie rolę swoistego agent provocateur $\mathrm{w}$ stosunku do dyskursów dominujących, wchodzących w skład porządku zwycięskiego. Żaden konflikt w kulturze nie pozostaje bez konsekwencji dla spójności i wiarygodności porządku, który się z niego wyłania. Konstatacja samych tych okoliczności wystarcza, moim zdaniem, do tego, by zagadnienie dziedzictwa pogańskiego i jego wielorakich interferencji ze zwycięską kulturą łacińską wyprowadzić ze sfery marginalności i uczynić częścią rodzimego dyskursu tożsamościowego.

Wydaje się, że dłuższe utrzymywanie (neo)poganizmu w kulturowym rezerwacie jest nie tylko niecelowe, ale też mało prawdopodobne: ma on zbyt wiele do zaoferowania tym (coraz liczniejszym) uczestnikom kultury współczesnej, którym konstruktywistyczne, odziedziczone po modernizmie formuły wspólnotowości jawią się jako niezadowalające, którzy orientując się na wartości esencjalne, poszukują ich nie w dominujących systemach aksjologicznych, ukształtowanych przez silne centra władzy dyskursywnej, lecz na peryferiach, często bardzo odległych.

Dla badaczy postkolonialnych powinien być to sygnał zachęcający do rewizji stereotypowego obrazu transferu kulturowo-cywilizacyjnego, jaki dokonał się między Zachodem a Wschodem Europy w związku z chrystianizacją tego drugiego. W ramach oficjalnej wykładni Zachód był tutaj donatorem, a Wschód beneficjentem, przy czym wiemy skądinąd, że do efektów tego transferu trudno zaliczyć obustronną korzyść, synergię, wdzięczność, współpracę etc., a więc wartości standardowo oczekiwane $w$ relacjach transferowych. Jest wręcz tak, że ów transfer pociągnął za sobą wiele nieczystych i niedopowiedzianych konsekwencji. Jedną z nich pozostaje kwestia nieprzepracowanych sprzeczności i dysonansów w ramach polskiego systemu samopostrzegania (vide rozbieżność między kultywacją typowo polskiego przywiązania do swojskości a kamuflowaniem pogańskich źródeł tej swojskości). Wspomniana wcześniej rewizja miałaby polegać na osadzeniu rzeczonego transferu na możliwie najszerszym tle historycznym, co wzbogaciłoby, a zarazem skomplikowało, perspektywę interpretacyjną. Ważnym elementem takiej rewizji powinno być również poszerzenie horyzontu peryferyjności jako istotnego czynnika współkształtowania polskiego habitusu. Wątki te, tak jak wiele innych, które zostały podniesione $\mathrm{w}$ artykule, wymagałyby jednak uszczegółowienia $\mathrm{w}$ ramach osobnego studium. 


\section{BIBLIOGRAFIA}

Bartkowski, Robert F. Połabie 983. Warszawa: Wydawnictwo Bellona, 2015.

Bauman, Zygmunt. Wspólnota. W poszukiwaniu bezpieczeństwa w niepewnym świecie. Przeł. Janusz Margański. Kraków: Wydawnictwo Literackie, 2008.

Domański, Henryk. Czy sa w Polsce klasy spoteczne?. Warszawa: Wydawnictwo Krytyki Politycznej, 2015.

Gieysztor, Aleksander. Mitologia Stowian. Warszawa: Wydawnictwa Uniwersytetu Warszawskiego, 2016.

Janion, Maria. Niesamowita Stowiańszczyzna. Fantazmaty literatury. Kraków: Wydawnictwo Literackie, 2016.

Lévi-Strauss, Claude. Smutek tropików. Przeł. Aniela Steinsberg. Warszawa: Aletheia, 2008.

Okraska, Remigiusz. W kregu Odyna i Trygława. Neopoganizm w Polsce i na świecie (zarys problematyki). Biała Podlaska: Rekonkwista, 2001.

Pankalla Andrzej Bronisław, Kośnik Konrad Kazimierz. „Duchowość Słowian z perspektywy psychologii noetycznej". Annales Universitatis Mariae Curie-Skłodowska, sectio J - Paedagogia-Psychologia, 1 (2017). S. 39-49.

Pasek, Zbigniew. „Zbawienie i natura - pytanie o projekt antropologiczny neopogaństwa”. Państwo i Społeczeństwo 4 (2013). S. 7-21.

Samsonowicz Henryk, Wyczański Andrzej, Tazbir Janusz et al. Polska na przestrzeni wieków. Warszawa: Wydawnictwo Naukowe PWN, 2009.

Skórczewski, Dariusz. „Trudności z tożsamością. Na marginesie Niesamowitej Stowiańszczyzny”. Porównania 5 (2008). S. 127-142.

Skórczewski, Dariusz. Teoria - literatura - dyskurs. Pejzaż postkolonialny. Lublin: Wydawnictwo KUL, 2013.

Słowiński, Zdzisław. „Neopogaństwo polskie w świetle systemowej teorii kultury”. Państwo i Społeczeństwo 4 (2008). S. 5-23.

Sowa, Jan, Fantomowe ciało króla. Peryferyjne zmagania z nowoczesna formą. Kraków: Universitas, 2011.

Strutyński, Maciej. Neopogaństwo. Kraków: Wydawnictwo WAM, 2014.

Sznirelman, Wiktor Aleksandrowicz. Nieojazyczestwo na prostorach Jewrazii. Red. W. A. Sznirielman. Moskwa: Biblejsko-bogosłowskij institut swiatogo apostoła Andrieja, 1999.

Thompson, Ewa. Trubadurzy imperium. Literatura rosyjska a kolonializm. Przeł. Anna Sierszulska, Kraków: Universitas, 2000.

Tomasiewicz, Jarosław. „Między tradycją i ponowoczesnością: neopoganie Europy Wschodniej w obliczu globalizacji”. Studia Religiologica 46 (2013). S. 339-349.

Urbańczyk, Przemysław. Mieszko Pierwszy Tajemniczy. Torun: Wydawnictwo Naukowe Uniwersytetu Mikołaja Kopernika, 2012.

White, Hayden. Przeszłość praktyczna. Przeł. Jan Burzyński, Agata Czarnacka, Tomasz Dobrogoszcz et al. Kraków: Universitas, 2014.

Zielina, Jakub. Wierzenia Prasłowian. Kraków: Wydawnictwo Petrus, 2012. 